\title{
El Partido Comunista en el movimiento obrero argentino durante la "Revolución Libertadora": del golpe de estado a la alianza entre el sindicalismo comunista y peronista (1955-1958)
}

\section{The Communist Party in the Argentine labor movement during the "Revolución Libertadora": from the coup d'état to the alliance among the communist and Peronist syndicalism (1955-1958)}

\begin{abstract}
Resumen
Este artículo se propone estudiar la intervención del Partido Comunista argentino en el movimiento obrero durante la "Revolución Libertadora". Se analiza la relación entre los planteos programáticos del partido y su participación en la Resistencia, la Comisión Intersindical, el Congreso normalizador de la CGT y la creación de las 62 Organizaciones en alianza con el sindicalismo peronista a partir de 1957.
\end{abstract}

Palabras Clave: movimiento obrero, comunismo, peronismo, Revolución Libertadora.

\begin{abstract}
This paper aims to study the intervention of the Communist Party of Argentina in the Labor Movement during the times of the "Revolución Libertadora". It analyzes the link between the programmatic claims of the party and its involvement in the Resistance, the Intersindical Commission, the Normalizing Congress of the CGT and the creation of the " 62 Organizaciones" in alliance with the Peronist sindicalism from 1957 on.
\end{abstract}

Keywords: labor movement, communism, Peronism, Revolución Libertadora

\footnotetext{
Argentino. Licenciado y Profesor en Sociología, Universidad de Buenos Aires. Email: e.murmis@hotmail.com 
Ezequiel Murmis, El Partido Comunista en el movimiento obrero argentino durante la "Revolución Libertadora": del golpe de estado a la alianza entre el sindicalismo comunista y peronista (1955-1958), Izquierdas, 28:114-136, Julio 2016

\section{Introducción}

La aparición del peronismo significó, entre otros aspectos, el desplazamiento de la influencia de las fuerzas de izquierda en la arena política y sindical. Tras años de reacomodamientos, la caída de Juan D. Perón y la instauración de la dictadura autodenominada "Revolución Libertadora" implicaron un rearmado de las fuerzas sindicales que abrió una oportunidad para que la izquierda - en general- y el comunismo en particular- recuperara sus posiciones. En el marco de la dictadura de 1955-1958, la lucha fundamental giró en torno a la aplicación de planes de racionalización y aumento de la productividad del trabajo, lo cual estuvo marcado por la proscripción política del peronismo y la intervención sindical encarada desde el Gobierno Provisional.

Los estudios historiográficos sobre el movimiento obrero en el período que se inicia en 1955 no dan cuenta de la actuación del Partido Comunista (PC) en el mundo del trabajo ${ }^{1}$, dejando así un vacío en el conocimiento sobre ese aspecto específico de la historia que cruza a la izquierda y los trabajadores en la Argentina. ${ }^{2}$ De conjunto, los diversos trabajos suelen presentar al período como el de la "Resistencia peronista". ${ }^{3}$ No obstante, dicho concepto oculta la participación de los trabajadores que intervinieron en la Resistencia desde referencias ideológicas alternativas al peronismo. ${ }^{4}$

En ese sentido, las investigaciones acerca del rol de la izquierda pos-1955 demuestran que existieron importantes diferencias de interpretación en torno al fenómeno peronista, lo cual se tradujo en disímiles estrategias y tácticas políticas para conquistar a una clase obrera mayoritariamente identificada con el peronismo. El Partido Socialista (PS) formó parte del antiperonismo, fomentó la "desperonización" del país y fue uno de los motores del llamado "sindicalismo libre". En paralelo, desde el trotskismo se practicó el "entrismo" en el movimiento obrero peronista, táctica orientada hacia la identificación con ese espacio con el objetivo de acercarse a las masas, profundizar procesos de radicalización y lograr la orientación de sectores militantes hacia el marxismo. En el caso de la organización liderada por Nahuel Moreno, que pasó a organizase como Movimiento de Agrupaciones Obreras y a editar el semanario "Palabra Obrera" (nombre con el que finalmente sería reconocido) tras la ilegalización del Partido Socialista de la Revolución

\footnotetext{
${ }^{1}$ Murmis, E. "Balances y perspectivas: acerca de la historiografía sobre el Partido Comunista argentino. Desde sus orígenes hasta los años '60.” XV Jornadas Interescuelas, Universidad Nacional de la Patagonia San Juan Bosco, Comodoro Rivadavia, septiembre 2015.

${ }^{2}$ Apenas se conocen estudios de caso acotados sobre el rol del PC en la comunidad obrera de Berisso y en los talleres ferroviarios de Libertad del Ferrocarril Midland. Ver Lobato, M. La vida en las fábricas. Trabajo, protesta y política en una comunidad obrera, Berisso (1904-1970). Prometeo, Buenos Aires, 2001; Sánchez, M. "El sindicalismo del PC en la UF ante los planes de racionalización ferroviaria (1955-1970)". VI Jornadas de la División Historia - III Taller de Historia Regional. Universidad Nacional de Luján. Luján, 2015.

${ }^{3}$ James, D. Resistencia e integración. El peronismo y la clase trabajadora argentina. Buenos Aires: Siglo XXI, 2006; Melon Pirro, J. C (2009) El peronismo después del peronismo. Resistencia, sindicalismo y política luego del 55. Buenos Aires: Siglo XXI.

${ }^{4}$ Schneider, A. Los compañeros. Trabajadores, izquierda y peronismo (1955-1973). Imago Mundi, Buenos Aires, 2005, p.71.
} 
Ezequiel Murmis, El Partido Comunista en el movimiento obrero argentino durante la "Revolución Libertadora": del golpe de estado a la alianza entre el sindicalismo comunista y peronista (1955-1958), Izquierdas, 28:114-136, Julio 2016

Nacional (PSRN), la participación en la Resistencia junto a los obreros peronistas llegó al punto de tomar parte de la simbología peronista para establecer un mayor acercamiento. ${ }^{5}$

El dilema acerca de qué hacer con el peronismo fue determinante en el proceso de renovación cultural y política que se lleva a cabo con el surgimiento de la llamada Nueva Izquierda. La fractura en el seno del PS entre un sector "ghioldista" (PS Democrático) y otro "renovador" (PS Argentino) en 1958 estuvo centrada en la búsqueda del grupo "renovador" por acercar al partido a las masas y terminar con años de antiperonismo6; a su vez, el acercamiento de Palabra Obrera al Frente Revolucionario Indoamericanista Popular (FRIP) de Santucho en los orígenes del Partido Revolucionario de los Trabajadores (PRT) fue un cambio de orientación luego del fracaso del "entrismo" ". Estos procesos expresan el clima político reinante en la izquierda, signado -entre otras cuestiones- por la condensación de dos aspectos significativos: la apertura que implica la caída de Perón para afirmarse entre los trabajadores y la necesidad de revertir el "error histórico" que implicó el alejamiento entre la izquierda y las masas obreras en 1945.

Estos lineamientos también atañen a la experiencia del PC. El presente artículo se inscribe en un estudio de historia social y política cuyo abordaje se sostiene en una metodología cualitativa. En el mismo se busca examinar la actuación del PC argentino durante la Revolución Libertadora de 1955-1958, haciendo hincapié en su política para la reorganización del movimiento obrero. En esos años, el comunismo fue parte activa de la resistencia en los sindicatos, protagonizando procesos destacados como la dirección de la Comisión Intersindical de 1957, la cual encabezó el proceso hacia la normalización de la CGT, cuyo desenlace sería la creación de las "62 Organizaciones", en una novedosa alianza entre el sindicalismo comunista y peronista.

La situación económica, social y política imperante bajo el gobierno de la dictadura es determinante para comprender el camino emprendido por el PC en el movimiento obrero. Tras el golpe perpetrado contra Perón, el avance sobre las condiciones de vida y de trabajo de la clase obrera se profundizó a partir del aumento de precios, el congelamiento de salarios, la postergación de las convenciones colectivas de trabajo y el establecimiento de medidas tendientes a la racionalización y el aumento de productividad. La intervención del sindicalismo en todos sus niveles y la proscripción al peronismo fueron elementos que sirvieron para confiscar a la clase obrera sus organismos de representación y la posibilidad de hacer política desde su principal referencia.

En ese marco, el PC encaró su lucha contra la dictadura y aprovechó el espacio abierto por la proscripción al peronismo y el desmantelamiento de su aparato sindical para ganar posiciones tras los años de hegemonía peronista en el movimiento obrero. Se advierte

\footnotetext{
${ }^{5}$ Camarero, H. "Una experiencia de la izquierda en el movimiento obrero. El trotskismo frente a la crisis del peronismo y la resistencia de los trabajadores (1954-1957)”, Razón y Revolución no 3, invierno 1997.

6 Tortti, M. C. El “viejo” Partido Socialista y los orígenes de la “Nueva Izquierda”. Tesis Doctoral. Universidad Nacional de La Plata. Facultad de Humanidades y Ciencias de la Educación, 2007. Disponible en: http://www.memoria.fahce.unlp.edu.ar/tesis/te.259/te.259.pdf

${ }^{7}$ Mangiantini, M. El trotskismo y el debate en torno a la lucha armada. Moreno, Santucho y la ruptura del PRT. El Topo Blindado, Buenos Aires, 2014.
} 
Ezequiel Murmis, El Partido Comunista en el movimiento obrero argentino durante la "Revolución Libertadora": del golpe de estado a la alianza entre el sindicalismo comunista y peronista (1955-1958), Izquierdas, 28:114-136, Julio 2016

en esta ocasión el despliegue de la estrategia frentista, tanto a nivel político como sindical. Como veremos, la misma tiene su antecedente en la década del '30, cuando los Partidos Comunistas adoptaron la estrategia de Frente Popular promovida por el Comintern. En el contexto de la dictadura -con las características económicas, sociales y políticas mencionadas- y con el principal referente en el movimiento obrero proscripto, el PC logró recuperar posiciones a nivel sindical.

La conjunción entre el contexto adverso para la clase obrera, el alza de la conflictividad social, el crecimiento del PC en el mundo del trabajo y su estrategia permeable a la acción conjunta con diversos sectores progresistas y democráticos, acercaron al sindicalismo comunista y peronista. La alianza se materializó fundamentalmente a partir de 1957, con la creación de la Comisión Intersindical y el posterior agrupamiento sindical en el que ambos compartieron la dirección, las 62 Organizaciones.

El estudio de los procesos destacados está encarado a partir del análisis de las posiciones del PC y su política en el movimiento obrero en términos generales. La revisión del semanario partidario Nuestra Palabra en los años en que se extiende la dictadura de la Revolución Libertadora (1955-1958) es la principal fuente primaria que aporta los datos sobre las caracterizaciones políticas y sociales por parte del PC, así como referencias a los diferentes conflictos en los que participa desplegando su estrategia en el movimiento obrero. Veremos, en una primera parte, los fundamentos programáticos sobre los que se asientan las visiones sobre el peronismo, la dictadura y los objetivos políticos perseguidos. En una segunda parte nos centraremos -sin adentrarnos en casos específicos de los gremios y determinados conflictos- en el análisis de la política del partido en el mundo del trabajo desde la asunción de Eduardo Lonardi hasta la creación de la Comisión Intersindical, momento en que el PC y la clase obrera dan un paso significativo en materia de organización para la defensa de sus condiciones de vida y de trabajo. Por último, analizaremos el rol cumplido por el comunismo en la elaboración del programa de la clase obrera en el año 1957.

\section{Estrategia comunista, peronismo y Revolución Libertadora}

El PC argentino estuvo desde sus orígenes alineado con la dirección de la Internacional Comunista (IC o Komintern). ${ }^{8}$ Adoptó así las distintas estrategias políticas impulsadas desde Moscú entre 1921-1935 en función de los diagnósticos establecidos acerca de la lucha de clases internacional y el camino hacia la revolución socialista.

La estrategia del período 1921-1928 fue la del Frente Único, que impulsaba la lucha del comunismo junto a diversas fuerzas de izquierda reformista (lo cual permitiría desenmascarar a sus direcciones) o de burguesías nacionales de países coloniales o "semicoloniales". En 1928 la misma fue alterada en el VI Congreso de la IC con la adopción de la línea de Clase contra clase correspondiente al tercer período. Se analizaba

\footnotetext{
${ }^{8}$ Gilbert, I. El oro de Moscú. Historia secreta de la diplomacia, el comercio y la Inteligencia soviética en la
} Argentina. Planeta, Buenos Aires, 1994. 
Ezequiel Murmis, El Partido Comunista en el movimiento obrero argentino durante la "Revolución Libertadora": del golpe de estado a la alianza entre el sindicalismo comunista y peronista (1955-1958), Izquierdas, 28:114-136, Julio 2016

la situación internacional en base al postulado que auguraba la crisis que traería consigo el final del capitalismo: se consideraba que en esta crisis los sectores medios jugarían un papel reaccionario con lo cual se prohibía el compromiso con corrientes reformistas y se establecía la idea de dos campos antagónicos: fascismo y comunismo. A su vez, se planteaba la necesidad de crear sindicatos revolucionarios escindidos de los sindicatos existentes.

La inserción del PC argentino en el mundo del trabajo comenzó en los '20 y creció al calor de la aplicación de las diversas estrategias políticas impulsadas por la IC. Aun bajo la estrategia de Frente único, desde 1925 la incursión en el medio obrero fue posible a partir de la bolchevización del partido, es decir, a partir de la adopción de los criterios del Komintern en materia de estructura partidaria. Se estableció la célula como unidad de organización en el taller o fábrica y la opción por el desarrollo de sindicatos únicos por rama. ${ }^{9}$ Cuando en 1928 se modificaron los tantos, el PC argentino se proclamó, en el VIII Congreso partidario de ese año, a favor de la estrategia del tercer período. En el mismo definieron las características de la estructura económica argentina en términos de un capitalismo atrasado, dependiente del imperialismo inglés y norteamericano, deformado por la persistencia del latifundio, cuya necesidad histórica era la realización de una revolución democrático-burguesa, agraria y antiimperialista. El correlato de esta estrategia en el mundo sindical fue la creación de sindicatos "rojos" por rama y de una central comunista en 1930, el Comité de Unidad Sindical Clasista (CUSC), espacios a partir de los cuales el comunismo encabezó importantes conflictos obreros. ${ }^{10}$

En 1935 la IC determinó en su VII Congreso un nuevo cambio de orientación: la nueva línea impulsaba la formación de frentes populares para luchar junto a diversas organizaciones progresistas y democráticas (inclusive sectores de la burguesía) contra el nazi-fascismo europeo de Hitler y Mussolini a la cabeza. En sintonía con la nueva apreciación, el PC se pronunció a favor del armado de un Frente Democrático Nacional antioligárquico, antiimperialista, compuesto por fuerzas democráticas y progresistas; en el plano sindical, resolvió disolver el CUSC e integrar la CGT en 1936 junto a socialistas y sindicalistas, al tiempo que modificó su inserción en los lugares de trabajo marcando el pasaje de la estructura celular a la organización de comisiones internas. ${ }^{11}$ La adopción del frente popular fue ratificada en 1938 en el IX Congreso del partido, configurando un horizonte socialista indeterminado que promovía una concepción etapista de la revolución

\footnotetext{
${ }^{9}$ Camarero, H. "El tercer período de la Comintern en versión criolla. Avatares de una orientación combativa y sectaria del Partido Comunista hacia el movimiento obrero argentino" A Contracorriente, vol. VII, 2011, North Carolina (USA), pp. 203-232.

${ }^{10}$ La lucha de los obreros en San Francisco está estudiada en Mastrángelo, M. Rojos en la Córdoba obrera 1930-1943. Buenos Aires: Imago Mundi, 2011.; las de los trabajadores de la madera en Camarero, H. y Ceruso. D. "Una historia del sindicato de la madera: organización gremial e influencia de la izquierda en las luchas obreras, Buenos Aires, 1917-1943" e-1@tina, Vol. 13, num. 50, Buenos Aires, enero-marzo 2015; las de los petroleros de Comodoro Rivadavia y la de los frigoríficos en 1932 están analizadas por Camarero $O p$ Cit., 2011.

${ }^{11}$ Ceruso, D. La izquierda en la fábrica. La militancia obrera industrial en el lugar de trabajo, 1916-1943. Imago Mundi, Buenos Aires, 2015.
} 
Ezequiel Murmis, El Partido Comunista en el movimiento obrero argentino durante la "Revolución Libertadora": del golpe de estado a la alianza entre el sindicalismo comunista y peronista (1955-1958), Izquierdas, 28:114-136, Julio 2016

social, cuya tarea inmediata sería la realización de una revolución democrático-burguesa. Entre la segunda guerra mundial, la burocratización de la URSS y la caída del stalinismo, el PC quedó encerrado en su caracterización de la estructura y en el planteo del Frente Democrático Nacional. Como se afirma en otro trabajo, "lo que siguió de allí en más y durante medio siglo fueron meras adecuaciones a los lineamientos". ${ }^{12}$ En este trabajo analizaremos la forma en que se puso en juego la estrategia unitaria en el movimiento obrero durante la Revolución Libertadora, lo cual implica estudiar, especialmente, la relación entre comunismo y peronismo.

Los "años peronistas" (1946-1955) fueron un verdadero quiebre en la historia argentina. Se asistió al establecimiento de un ordenamiento político compuesto por la alianza entre las Fuerzas Armadas, sindicatos, corporaciones patronales de capital nacional y la Iglesia. El régimen liderado por Juan D. Perón arbitró entre las clases sociales a partir de la consolidación de un 'modelo' económico de industrialización (cuya tendencia se observaba en décadas previas) con participación económica, política y social de la clase obrera. En el marco del aumento de la demanda de mercancías agrarias, el Estado se convirtió en el principal apropiador de la renta de la tierra, propiciando un sostén a los pequeños capitales industriales y una política económica redistributiva. ${ }^{13} \mathrm{El}$ peronismo logró rápidamente la hegemonía en el sindicalismo (represión e intervencionismo estatal mediante) y el "orden social" se estableció a partir de la creación de empleos e incrementos tanto a nivel del salario, el consumo y las negociaciones colectivas.

Hacia la segunda presidencia de Perón la política económica mostró sus límites, fundamentalmente a partir del crecimiento de la inflación, de la carestía de vida y la crisis en la balanza de pagos. En el marco del establecimiento del Segundo Plan Quinquenal iniciado en 1952, se optó por desarrollar la industria pesada, promover inversiones extranjeras y atacar las condiciones de trabajo de la clase obrera a partir de la intensificación del trabajo y el aumento de la productividad. Este último punto es la clave para la entender el paso del peronismo al golpe de Estado de 1955: la burguesía buscó incrementar el plusvalor vía racionalización y aumentos de productividad del trabajo, lo cual fue recogido por el gobierno con la celebración de la negociación colectiva de 1954 y el Congreso de la Productividad y el Bienestar Social en 1955. Aunque logró imponer sus intereses en determinadas ramas ${ }^{14}$, los resultados del Congreso fueron un fracaso para la burguesía, que se encargó de organizarse para el derrocamiento de Perón.

\footnotetext{
12 Camarero, H. "Tras las huellas de una ilusión: el Partido Comunista argentino y sus planteos del Frente Democrático Nacional (1955-1963)". Revista Archivos de historia del movimiento obrero y la izquierda. Año III, N 5, sept. 2014, p. 31.

${ }^{13}$ Peralta Ramos, M. Acumulación de capital y crisis política en la Argentina (1930-1974). Buenos Aires, Siglo XXI, 1973.

${ }^{14}$ Acerca de la negociación colectiva y las luchas en las diversas ramas, véase Kabat. M. "Resistencia obrera a la flexibilidad laboral, un análisis de la negociación colectiva en 1954." XIV Jornadas Interescuelas/Departamentos de Historia, Universidad Nacional de Cuyo, Mendoza, 2013.; Schiavi, M. La resistencia antes de la resistencia. La huelga metalúrgica y las luchas obreras en 1954, Buenos Aires, El Colectivo, 2008.
} 
Ezequiel Murmis, El Partido Comunista en el movimiento obrero argentino durante la "Revolución Libertadora": del golpe de estado a la alianza entre el sindicalismo comunista y peronista (1955-1958), Izquierdas, 28:114-136, Julio 2016

Si el peronismo fue un quiebre en la historia argentina, su caída y el establecimiento de la Revolución Libertadora también significó un punto de inflexión a nivel político, económico y social en el país. El final del peronismo en el gobierno inauguró un período político de "empate hegemónico", caracterizado por la incapacidad de las clases dominantes para construir una forma de dominación legítima y reproducible, cuyos intentos de resolución se vieron sucesivamente truncados. ${ }^{15}$ Apoyada por la Iglesia, los capitales extranjeros y partidos importantes como la UCR ${ }^{16}$, PDP y PS, la Revolución Libertadora fue el primer intento de establecimiento de un orden político basado en la desarticulación del sindicalismo: encaró la "desperonización” del país y confiscó la organización sindical a partir de su intervención en todos los niveles. Su objetivo era garantizar la alteración del modelo de acumulación de capital ${ }^{17}$ que venía produciéndose desde fines del gobierno peronista, el cual implicaba un ataque a las condiciones de vida y de trabajo de la clase obrera. Desde los inicios del ciclo abierto en 1955, los trabajadores demuestran su protagonismo, fundamentalmente a partir de su lucha contra la dictadura, la proscripción política, la intervención sindical, la represión, los planes de productividad y la carestía de vida.

La comprensión acerca de la relación entre comunismo y peronismo para el período 1955-1958 está sujeta a la contemplación de dos aspectos significativos. En primer lugar, es menester atender al hecho de que, a pesar de ser una de las corrientes dominantes en el movimiento obrero de los '40, el PC interrumpió su crecimiento en el mundo del trabajo a partir de la acción represiva del gobierno de facto asumido en 1943. La disolución de la CGT $\mathrm{n}^{\circ} 2$ dominada por los comunistas, la clausura de los locales de sindicatos comunistas y la detención de sus dirigentes respondieron al intento de neutralizar a un sindicalismo cada vez más comprometido y político en un contexto de alza de la conflictividad. ${ }^{18} \mathrm{El}$ espacio libre que dejaron los comunistas en los sindicatos fue rápidamente aprovechado por las listas disidentes de cada gremio, las cuales crearon sindicatos paralelos que recibieron el apoyo oficial.

El segundo aspecto radica en los cambios producidos por el comunismo en su interpretación del peronismo en 1946. Tras haber participado de la coalición que se opuso al peronismo en las elecciones ${ }^{19}$, el PC dio un revés en su XI Congreso: abandonó la caracterización de nazi-fascismo y entendió al peronismo como una fuerza compuesta por

\footnotetext{
${ }^{15}$ Portantiero, J. C. "Economía y política en la crisis argentina, 1958-1973", en Ansaldi, W. y Moreno, J. L. (comp.), Estado y sociedad en el pensamiento nacional, Buenos Aires, Cántaro, 1996, pp. 301-346.

${ }^{16}$ Luego se dividirían en UCRP y UCRI, conducidos por Balbín y Frondizi respectivamente.

${ }^{17}$ Peralta Ramos, M. Op Cit.

18 Las principales acciones de los gremios comunistas, sobre todo en la rama metalúrgica, textil y construcción en los primeros años de la década del cuarenta, están analizados en: Gurbanov, A. y Rodríguez, S. "La huelga metalúrgica de 1942 y la dirigencia comunista en los orígenes del peronismo". Nuevo Topo $\mathrm{n}^{\circ}$ 4, Buenos Aires, 2007, pp. 61-83; Videla, O. y Menotti, P. "Una experiencia de la militancia comunista en los orígenes del peronismo. El Sindicato de Obreros de la Industria Metalúrgica (SOIM) de Rosario" $A$ contracorriente, $\mathrm{n}^{\circ} 2$, vol. 11, 2014, pp. 114-144; Ceruso, D. Op Cit.; Schiavi, M. "Los sindicatos comunistas entre el 17 de octubre y su disolución. El caso textil y metalúrgico.” Trabajadores, Año II. No 3, 2012.

${ }^{19}$ En la Unión Democrática participaron el Partido Socialista, el Demócrata Progresista y Unión Cívica Radical.
} 
Ezequiel Murmis, El Partido Comunista en el movimiento obrero argentino durante la "Revolución Libertadora": del golpe de estado a la alianza entre el sindicalismo comunista y peronista (1955-1958), Izquierdas, 28:114-136, Julio 2016

grupos heterogéneos con intereses contrapuestos, lo cual desataría una lucha entre sectores progresistas y reaccionarios. En función de esta nueva lectura, el PC intentó participar de la lucha por la imposición del sector progresista al interior del peronismo, a partir del armado de un Frente de Liberación Social y Nacional que unificara a los sectores antioligárquicos y antiimperialistas, sin distinciones ideológicas ni religiosas. Se buscó construir así el camino hacia una revolución democrática, bajo una dinámica sostenida en apoyar las medidas progresistas del gobierno y criticar las regresivas. ${ }^{20}$ Integrados a la CGT, los militantes comunistas dieron esa batalla con la creación en 1949 de su agrupación sindical, el Movimiento Pro Democratización e Independencia de los Sindicatos, desde donde lucharon contra la carestía de vida, los despidos y las persecuciones. No obstante su posición en el mundo del trabajo continuó siendo marginal. ${ }^{21}$

El PC recibió al golpe como parte del ciclo inestable de golpes y contragolpes iniciado en 1930. Postuló una continuidad entre el peronismo y el gobierno de facto, fundamentalmente por dos situaciones en estrecha relación. En primer lugar, entendió que la orientación económica era similar a la de los últimos años del peronismo, sobre todo desde la crisis económica iniciada en 1949 y el Segundo Plan Quinquenal. En un contexto de inflación y congelamiento de salarios por dos años, el cuadro de avance sobre las condiciones de vida y de trabajo de la clase obrera se completaría con la celebración de la negociación colectiva de 1954 y el Congreso de la Productividad. Retomando este proceso, la Revolución Libertadora dio sus primeros pasos implementando el Plan Prebisch como salida a la crisis económica que se arrastraba desde 1949. El PC consideró que los motivos del plan se encontraban en descargar la crisis sobre los hombros de los trabajadores, al negar aumentos salariales, incrementar la desocupación y la carestía de vida. ${ }^{22}$ Entre los puntos de continuidad a destacar entre la orientación económica del peronismo a partir de los años ' 50 y el Plan Prebisch, se señalaba el mantenimiento del latifundio como estructura productiva; la devaluación de la moneda para paliar la crisis de la balanza de pagos; la promoción de la industria petrolera y siderúrgica; la promoción de inversiones extranjeras; los limitados aumentos salariales y su congelación en un contexto de inflación; y, fundamentalmente, la preocupación por el aumento de la productividad del trabajo.

En segundo lugar, el PC comparó la política sindical del peronismo y la Revolución Libertadora en tanto establecieron una organización verticalista, con un férreo control gubernamental de la dirigencias. Denunció tanto la intervención de los sindicatos organizada por el "corporativismo-fascista" de Perón como la dictada por Lonardi -que

\footnotetext{
${ }^{20}$ Staltari, S. "El Partido Comunista frente al peronismo: estrategia y tácticas políticas, 1945-1955” Revista Archivos de historia del movimiento obrero y la izquierda. Año III, N 5, 2014, pp 11- 30.

${ }^{21}$ Contreras, G. "La organización del movimiento obrero durante el primer peronismo (1946 - 1955$)$ : nucleamientos sindicales y centrales obreras. Primeros avances de investigación y propuestas para un análisis desde la historia social y la historia política" V Jornadas Nacionales de Historia Social, La Falda, Córdoba, 2015 .

22 “Unidad obrera frente al decreto de intervención a los gremios". Nuestra Palabra, no 288, 8/11/55, p. 1 y 6.
} 
Ezequiel Murmis, El Partido Comunista en el movimiento obrero argentino durante la "Revolución Libertadora": del golpe de estado a la alianza entre el sindicalismo comunista y peronista (1955-1958), Izquierdas, 28:114-136, Julio 2016

contó con el aval de las autoridades de la $\mathrm{CGT}^{23}$ tras la ocupación por parte de los "Comandos Civiles Revolucionarios"

De acuerdo a esta interpretación en clave de continuidad entre un gobierno y otro, en los días posteriores al golpe, el Comité Central del PC afirmó que

lo característico de los sucesos que cubren el periodo del 16 al 22 de septiembre es la conducta deliberada de ambas partes - Gobierno peronista y sectores militares sublevados- dirigida a impedir la participación del pueblo en la solución del problema político del país. ${ }^{25}$

En ese sentido se analizó la capitulación del gobierno peronista, que se negó a armar al pueblo para su defensa. Como sostuvo el PC,

Las masas obreras no pueden perdonar a quienes no les dieron armas para luchar contra los golpes el 16 de junio: las dejaron expuestas a los bombardeos de la oligarquía y el imperialismo. La CGT no encaró la dirección en ese objetivo sino que puso a los trabajadores a disposición del Ejército. ${ }^{26}$

En la Declaración del partido se afirmaba que el gobierno de facto tenía una composición heterogénea con propósitos disímiles, sobre la que presionaban el imperialismo y la burguesía para imprimir al mismo un curso reaccionario. En ese sentido, el PC abrigaba esperanzas en que los sectores progresistas intervengan en el nuevo proceso liderado por Lonardi para darle una salida democrática. La táctica inalterada desde 1935 de Frente Popular se puso en juego enseguida. Lejos de reclamar el retorno de Perón, el PC consideraba que la lucha era por el establecimiento de un régimen democrático que se distancie del "corporativismo-fascista". Los fundamentos estratégico-tácticos y la herramienta política para llevar a cabo sus objetivos, fueron los mismos que los establecidos tras el cambio de visión acerca del peronismo en el XI Congreso partidario de 1946: el frente popular y su organismo, el Frente Democrático Nacional. En la nueva situación política, el PC llamó a luchar contra la dictadura a partir de la unión de los distintos partidos que estén a favor de la paz, la libertad, la prosperidad y la independencia, para la constitución de un Gobierno de Coalición Democrática. Como veremos, el correlato de esta política frentista junto a los sectores democráticos y progresistas se expresó en el movimiento obrero a partir de la acción unitaria impulsada por el PC a lo largo de la Revolución Libertadora.

\footnotetext{
${ }^{23}$ Idem

24 "Las metralletas sirven para todo, menos para dirigir el movimiento obrero" Nuestra Palabra, $\mathrm{n}^{\circ} 284$, $11 / 10 / 55$, p. 1.

25، ¿Hacia dónde marcharán los acontecimientos? Declaración del CC del PC después del reciente levantamiento militar y la constitución del gobierno provisional" Nuestra Palabra, no 282, 27/9/55, p. 1 a 4.

26 "Las milicias obreras" Nuestra Palabra, n'281, 20/9/55, p. 5
} 
La iniciativa del PC en el plano sindical de los años que trabajamos se encontraba de la mano del Movimiento Pro Democratización e Independencia de los Sindicatos, una agrupación sindical creada en 1948 como organización intermedia que sirviera para interpelar a los obreros y establecer un acercamiento entre ellos y el partido, con el objetivo último de guiarlos hacia la conformación del Frente. En ocasión del golpe, el Movimiento se diferenció de la CGT al impulsar la política de armamento y defensa de la libertad desde los lugares de trabajo y sindicatos. Tempranamente el Movimiento expuso un documento en el que sentaba las bases del plan a seguir contra la dictadura. Inspirado en su política frentista junto a los obreros sin importar ideología, constaba de trece puntos principales, entre ellos: la realización de asambleas generales deliberativas, democráticas; la reincorporación de militantes cesanteados; la lucha por la independencia de clase de sindicatos y CGT, del Estado y patrones; la unidad sin discriminaciones políticas; el restablecimiento de libertades democráticas y sindicales; la unidad sindical en una única Federación Nacional por Industria y una única CGT; la defensa de comisiones internas y delegados elegidos democráticamente; y el llamado a la realización de un Congreso Extraordinario de la CGT. ${ }^{27}$ Apuntaba así a defender y recoger los derechos e intereses de las bases obreras y a luchar por la unidad en una CGT independiente del gobierno y la burguesía.

\section{La lucha por recuperar posiciones (1955-1956)}

La intervención sindical encarada por la Revolución Libertadora implicó una reorganización en el movimiento obrero, lo cual significó una apertura para diversos sectores que se encontraban relegados en el mismo. El PC participó activamente para recuperar sus posiciones tras la experiencia del peronismo. En los años que se extiende la dictadura pueden dividirse dos etapas: los meses del General Eduardo Lonardi en el poder, del 16 de septiembre al 13 de noviembre de 1955; y el período que se corresponde con la presidencia de Pedro E. Aramburu y se prolonga hasta la apertura democrática, el $1^{\circ}$ de mayo de 1958, cuando Arturo Frondizi asume el gobierno.

El primer período representó, en materia sindical, un interregno en la relación entre el movimiento sindical peronista y las autoridades no peronistas. Entendiendo a los sindicatos como espacios de control social, Lonardi consideraba viable un triunfo del peronismo, aunque despojado de sus "vicios". Pretendió establecer un tono conciliador con la CGT que permitiera iniciar una política de negociación con el sindicalismo peronista. Se tendió un puente entre la cúpula sindical y el Gobierno Provisional: el Secretario General de la CGT, Di Pietro, llamó a los trabajadores a mantener la calma tras el golpe, al tiempo que el gobierno, de la mano del Ministro de Trabajo Cerruti Costa, se comprometió a mantener la estructura sindical del peronismo. ${ }^{28}$

\footnotetext{
27 “El Movimiento Pro Democratización e Independencia de los Sindicatos expone en un documento las medidas por las que debe luchar la clase obrera en unidad de acción" Nuestra Palabra, n 284, 11/10/55, p. 4. ${ }^{28}$ James, D. Op Cit., pp 69-77.
} 
Ezequiel Murmis, El Partido Comunista en el movimiento obrero argentino durante la "Revolución Libertadora": del golpe de estado a la alianza entre el sindicalismo comunista y peronista (1955-1958), Izquierdas, 28:114-136, Julio 2016

El principal proceso que atravesó la relación Gobierno Provisional-CGT estuvo marcado por la ocupación de sindicatos y el acuerdo establecido entre ambos para normalizar la situación. Hacia fines de septiembre de 1955, grupos antiperonistas armados, denominados Comandos Civiles Revolucionarios, asaltaron y ocuparon locales de numerosos sindicatos (gráficos, ferroviarios, bancarios, vestidos, petroleros, trabajadores de la carne, etc). Esa situación produjo la renuncia del secretariado de la CGT, cuyo reemplazo estuvo a cargo de Andrés Framini y Luis Natalini. Si bien la situación pareció encontrar su cauce tras el acuerdo contraído en octubre entre la central sindical y el Gobierno -que establecía la designación de interventores en los sindicatos ocupados por antiperonistas (en general socialistas o radicales) y un período de 120 días para celebrar elecciones libres en todos los gremios-, lo cierto es que el acuerdo se evidenció rápidamente inviable hacia noviembre, trayendo consigo la caída de Lonardi y el ascenso de Aramburu.

Es destacable el hecho de que, en el corto período en el que Lonardi es presidente de facto, el PC tuvo una posición titubeante en las primeras acciones de la Resistencia. ${ }^{29} \mathrm{~A}$ pesar de criticar al gobierno de facto, a la cúpula sindical de la CGT y a los Comandos Civiles asaltantes, el Movimiento se pronunció junto al "sindicalismo libre" 30 contra la manifestación del 17 de octubre por entenderla como una "acción obstruccionista de políticos y dirigentes desplazados, que servían el régimen depuesto". ${ }^{31}$ En el comunicado reproducido en Nuestra Palabra, se expresó la negativa por tratarse de una acción desorganizada y motivada por "objetivos que no son comunes a todos los trabajadores". 32 No obstante, ante el accionar represivo del gobierno y el sorprendente acatamiento del paro de las bases peronistas, la militancia comunista del Movimiento se manifestó a favor de los derechos sindicales y las libertades democráticas de los trabajadores y llamó a la unidad de peronistas y no peronistas en la lucha por lograr la independencia de los sindicatos y la CGT, el levantamiento del estado de sitio, la constitución del Frente Democrático Nacional y el establecimiento de un gobierno de coalición democrática. También se opusieron a la frustrada huelga general convocada para el 3 de noviembre por la CGT, a realizarse en oposición al decreto-ley del 28 de octubre de intervención de los sindicatos y celebración de nuevas elecciones, precisamente por haber sido dispuesta por los "jerarcas sindicales". 33

Durante el gobierno de Lonardi, el PC se mantuvo en la oposición, así como se distanció del depuesto gobierno de Perón; se opuso a los primeros informes de Prebisch y a

\footnotetext{
${ }^{29}$ A diferencia del PC, la Federación Bonaerense del PSRN (trotskista) participa de estas primeras acciones de resistencia a partir de la convocatoria a la realización de una huelga general para el 17 de octubre de 1955, recogiendo los intereses de las bases obreras peronistas a partir de su simbología y ligándose a ellas en el marco del desarrollo del "entrismo". Camarero, H. Op Cit, 1997, pp 22-23; González, E. (coord.) El trotskismo obrero e internacionalista en la Argentina. Tomo II. Antídoto, Buenos Aires, 1996, p. 28.

${ }^{30}$ Este llamado es compartido con el Movimiento Pro Recuperación del Sindicalismo Libre (Pérez Leirós), la Comisión interventora de la Federación Gráfica Argentina, la Unión de Trabajadores de la Industria del Calzado, el consejo directivo de la Asociación Obrera Textil, el Sindicato de Estibadores Portuarios Auténticos, la Junta interventora en la Asociación Bancaria, la intervención de la Federación Obrera Nacional de la Industria del Vestido y Afines y otras.

31 "Será reprimido todo intento de perturbación" La Nación, 16/10/55, p.1

32 "Lo del 17" Nuestra Palabra n 286, 25/10/55, p.6.

${ }^{33}$ Frente al decreto ley junidad, democracia e independencia sindical! Nuestra Palabra ${ }^{\circ}{ }^{287}, 1 / 11 / 57$, p. 7
} 
Ezequiel Murmis, El Partido Comunista en el movimiento obrero argentino durante la "Revolución Libertadora": del golpe de estado a la alianza entre el sindicalismo comunista y peronista (1955-1958), Izquierdas, 28:114-136, Julio 2016

la intervención en los sindicatos, al igual que dirigió sus críticas tanto a la dirigencia sindical peronista que mantuvo acuerdos con el gobierno como al nuevo "sindicalismo libre" que pretendía apoderarse de los sindicatos. Aun apoyando a las bases trabajadoras en su lucha por las condiciones de vida y de trabajo, por el restablecimiento de sus derechos, no supo estar a su lado en las principales luchas del período. La situación se vería modificada en el gobierno siguiente, que encaró una ofensiva más pronunciada contra los trabajadores.

La asunción de Aramburu demostró un cambio de orientación en política sindical. La primera medida adoptada en ese sentido fue la declaración de ilegalidad de la huelga general convocada por la CGT y la intervención de la misma, a tres días de asumido el poder. La política del nuevo gobierno siguió dos líneas principales: se atacó al sindicalismo tanto en el plano de las dirigencias sindicales peronistas como el de las comisiones internas, lo cual se tradujo en arrestos y destituciones; y llevó a cabo las medidas recomendadas por Prebisch tendientes a racionalizar y aumentar la productividad a partir de la firma del decreto 2739 de febrero 1956. El interés por alterar las condiciones de explotación de la clase obrera requería la anulación de las conquistas sociales y económicas; para ello, debía atacar su organización sindical.

La intervención de la CGT y sus organismos -dictada con el decreto 3032/55- dejó también caducas las comisiones internas y los mandatos de delegados ${ }^{34}$. Luego del ataque a los organismos obreros dentro y fuera de fábrica, el gobierno impulsó el establecimiento del Plan Prebisch a partir del nuevo informe de enero 1956 llamado "Plan de Restablecimiento Económico", en el que incorporaba aumentos salariales y un plan de despidos en el sector ferroviario. Rápidamente, la avanzada sobre las condiciones de trabajo y de vida de la clase obrera se tornó más pronunciada a partir de febrero de 1956 con la firma del decreto-ley 2739. En un contexto de alza de la carestía de vida -dado por la inflación, los congelamientos salariales dispuestos en las negociaciones colectivas de 1954 y la derogación de las resoluciones que limitaban los precios de artículos de primera necesidad $^{35}$-, mientras la clase obrera se preparaba para la negociación colectiva dispuesta para febrero, el Gobierno provisional prorrogó la vigencia de los convenios colectivos de trabajo hasta la homologación de los que se establecieran en su reemplazo. Como medida de emergencia, concedió un aumento del 10\% sobre los jornales, sueldos y salarios que se percibían al 31/1/56. El decreto derogó las cláusulas de los convenios anteriores que no convenían a la superexplotación; incorporó incentivos morales y materiales con vistas a la intensificación del ritmo y la cantidad de trabajo; promovió la realización de horas extra; dio rienda libre para los criterios de promoción, que dejaban sin efecto a la antigüedad y estructuraban un régimen meritocrático. A su vez, incorporó en su art. 8 la movilidad laboral al interior de la fábrica en pos del aumento de productividad. Se dejó en claro que

\footnotetext{
${ }^{34}$ Fueron designados nuevos desde arriba en función de su antigüedad en las empresas

35 "El gobierno acelera la carestía: el pueblo debe unirse en defensa de su nivel de vida" Nuestra Palabra, $\mathrm{n}^{\circ}$ $292,6 / 12 / 55$, p.4.
} 
Ezequiel Murmis, El Partido Comunista en el movimiento obrero argentino durante la "Revolución Libertadora": del golpe de estado a la alianza entre el sindicalismo comunista y peronista (1955-1958), Izquierdas, 28:114-136, Julio 2016

los nuevos acuerdos sobre salarios estarían sujetos a circunstancias relacionadas con la productividad. $^{36}$

La conflictividad social del año 1956 estuvo marcada por la lucha en torno a salarios, convenios, detenciones y despidos, lo cual se inscribió en una lucha aún más amplia por la recuperación de los sindicatos a manos de sus trabajadores. Desde finales de 1955 el PC pareció intervenir con mayor decisión en los conflictos: un ejemplo de ello fue su participación en la huelga general convocada por la CGT para el 14 de noviembre, que difirió de su abstención en los conflictos mencionados durante los meses de Lonardi en el gobierno. Aunque el PC consideró esta huelga como un capítulo nuevo de las maniobras de los jerarcas sindicales, resolvió intervenir para reorientar el programa de la misma, reclamando democracia e independencia sindical, aumentos salariales de emergencia y alentando una movilización en lugar de una huelga pasiva. ${ }^{37}$

En función de las medidas dispuestas por el gobierno, el PC convocó a intensificar la lucha desde abajo a partir del armado de Comités unitarios de lucha en cada lugar de trabajo, dotados de un programa que surgiera de las deliberaciones democráticas al interior de las Comisiones Internas. También llamó a votar delegaciones de las comisiones internas para formar Comisiones Provisorias en cada gremio, encargadas de convocar a elecciones en los gremios en un plazo de 60 días, sobre la base de la representación proporcional. ${ }^{38}$ Fueron meses de intensa actividad para el Movimiento Pro Democratización, que contaba en diciembre en 1956 Comisiones unitarias representantes en 28 gremios distintos. ${ }^{39}$

El Gobierno de Aramburu encaró en ese año la negociación colectiva y la normalización de los sindicatos mediante mecanismos que pretendían servir a los intereses de la burguesía. En primer lugar, se destaca la convocatoria realizada en marzo para elegir delegados para conformar las Comisiones Paritarias. El PC advirtió el contenido antidemocrático de la resolución, que fijaba las elecciones sólo en algunos establecimientos, excluyendo a los demás obreros de la negociación. Las mismas se realizarían en diez establecimientos grandes, diez medianos y diez pequeños, obteniendo cada uno de ellos un delegado; luego, el interventor designaría doce de esos treinta delegados, de los cuales nueve serían titulares y tres suplentes. A su vez, los obreros menores de 25 años, los extranjeros y aquellos que contaban con una antigüedad menor a tres años quedaban excluidos de la posibilidad de ser electos. ${ }^{40}$ Era también un ataque al peronismo, en tanto un nuevo decreto de abril -el 4258/56- inhabilitaba a participar de las

\footnotetext{
${ }^{36}$ James, Op Cit, p. 90-91

37 "Altiva y dispuesta a ganar su independencia y unidad, volvió al trabajo la clase obrera" Nuestra Palabra, n $^{\text {o } 290,22 / 11 / 55, \text { p. } 1 \text { y } 2 .}$

38 “El Movimiento pro democratización fue durante la huelga la auténtica voz de los trabajadores". Nuestra Palabra, no 290, 22/11/55, p. 8.

${ }^{39}$ Los 28 gremios representados son: metalúrgico, textil, ferroviario, transporte, construcción, petróleo, gráfico, luz y fuerza, agua y energía, marítimo, maderero, empleados del estado, de la alimentación, comercio, caucho, tabaco, calzado, vestido, bancario del seguro, viajantes de comercio, músico, panadero, gastronómico, del vidrio, periodístico, camionero y del cuero. Listado en: "Una gran conferencia realizó el Movimiento Pro Democratización e Independencia de los Sindicatos de la Capital” Nuestra Palabra, no 292, 6/12/55, p. 6.

40 “Los obreros repudian las normas electorales totalitarias". Nuestra Palabra, no 307, 4/4/56, p.7.
} 
Ezequiel Murmis, El Partido Comunista en el movimiento obrero argentino durante la "Revolución Libertadora": del golpe de estado a la alianza entre el sindicalismo comunista y peronista (1955-1958), Izquierdas, 28:114-136, Julio 2016

Comisiones Paritarias a los trabajadores que desempeñaron cargos de representación o dirección en sus empresas y gremios. ${ }^{41}$ Se pretendía así proscribir a un estrato de dirigentes y favorecer el surgimiento de uno nuevo. En sintonía con estas maniobras, el Gobierno prohibió la realización de asambleas y la propaganda al tiempo que fijó la autoridad del Tribunal Arbitral para decidir en caso de no llegar a acuerdos en el lapso de 30 días. ${ }^{42}$

Ante este proceder antidemocrático, el comunismo exhortó a los obreros a formar Comisiones Unitarias de lucha en todos los lugares de trabajo para lograr la democratización del proceso de negociación colectiva, que permita contemplar los intereses de las bases obreras sin distinción ideológica o religiosa ${ }^{43}$. Como bien señala James, aunque se avanzó de facto en la eliminación de obstáculos a la productividad, no hubo una aplicación total de los planes de racionalización ni renovación general de los convenios colectivos. ${ }^{44}$ Hacia finales de agosto, el PC advirtió que "sólo una ínfima cantidad de gremios finiquitaron las tratativas y no son, por cierto, los más importantes ni los más numerosos". ${ }^{45}$ Esta situación se extendió por meses en sindicatos importantes como el metalúrgico, ferroviario ${ }^{46}$, textil $^{47}$ y de la construcción. En buena medida eso se debió a la resistencia de las bases obreras, proceso en el que el PC tuvo su incidencia, fundamentalmente en sectores como madera, estibadores portuarios, frigoríficos, calzado, transporte, telefónico, ferroviario, construcción, textil, entre otros. ${ }^{48}$. Participó activamente desde las Comisiones Unitarias en la lucha por aumentos salariales, por la negociación de convenios, en la defensa de las conquistas obreras, contra los despidos y cesantías y por la liberación de los militantes presos.

En paralelo a la lucha en torno a los convenios colectivos se desarrolló el proceso de normalización sindical, del cual el Movimiento Pro Democratización también fue parte activa. Anunciadas el $1^{\circ}$ de mayo —a realizarse en un lapso de 150 días —, las elecciones sindicales se convocaron en dos partes: en julio-agosto se efectuarían los comicios para

\footnotetext{
41 Más precisamente, “inhabilita para el desempeño de cargos públicos, empleos estatales y direcciones políticas a millares de personas que militaron en el peronismo, metiendo en una misma bolsa a quienes ocuparon altos cargos de gobierno y a quienes figuraron en las múltiples secretarías y unidades básicas y en las bancadas de tantas pequeñas municipalidades como hay en el país". Ver: "Decreto maldito". Nuestra Palabra, n'312, 9/5/56, p.1.

42 "Unidad, organización y lucha para conquistar los convenios y rescatar los sindicatos" Nuestra Palabra, $\mathrm{n}^{\circ}$ $325,15 / 8 / 56$, p. 6.

43 “Organizar comisiones unitarias” Nuestra Palabra n³10, 25/4/56, p.4.

${ }^{44}$ James, Op Cit, pp 93-94.

45 "El derecho a luchar". Nuestra Palabra n'327, 29/8/56, p.7.

46 “Convenio justo pide el gremio del riel” Nuestra Palabra n³51, 27/2/57 p.4.

47 "Más de 200.000 obreros pararon en todo el país" Nuestra Palabra n³37, 7/11/56, p.4.

${ }^{48}$ Véase respectivamente para cada gremio: ¡Unidad de acción para rescatar al sindicato! Nuestra Palabra $\mathrm{n}^{\circ}$ 309 p. 6.; "Triunfalmente luchan los estibadores portuarios" Nuestra Palabra n”306, p.6; "Coordinan su acción nacional los obreros de la carne" Nuestra Palabra n³07, p.6 y en Swift de Rosario, Nuestra Palabra n³13 p. 7.; "El gremio del calzado rodea unido a su Comisión provisoria coordinadora" Nuestra Palabra n³08, p.7; "Los comunistas de la comisión” Nuestra Palabra n³15, p.7.; “Telefónicos" Nuestra Palabra n³22, p.6.; "Los obreros ferroviarios enfrentan la agresión contra sus conquistas" Nuestra Palabra n³24, p.6.; "La construcción del Gran Buenos Aires paró 24hs" Nuestra Palabra n" 328, p.6.; "Se concentran los textiles el 25" Nuestra Palabra n'326, p.7
}

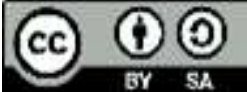


designar Comisiones Internas; hacia mediados de septiembre, para Comisiones Directivas. $^{49}$ Según lo dispuesto, las elecciones serían por listas que deberán ser oficializadas en cada sindicato ante el interventor y contar con el auspicio de sus afiliados. ${ }^{50}$ Controlada por los interventores y la Junta Escrutadora, la votación se realizaría por listas completas —diferenciadas por color-, obteniendo la lista mayoritaria las dos terceras partes de los cargos en la comisión y la segunda el tercio restante.

El PC se opuso tanto al criterio de representación como a la escasa participación de los obreros en el proceso electoral: propuso realizarlas en base a la representación proporcional y bajo el control de los propios obreros a partir de la elección de Comisiones Electorales. Entendiendo que los procedimientos eran arbitrarios, divisionistas y antidemocráticos, su propuesta consistió en intervenir en las elecciones a partir de la presentación de Listas Unitarias en todos los gremios que representen a todos los trabajadores sin distinciones políticas o religiosas. El principal objetivo que guió esta política fue el de recuperar los sindicatos y la CGT y poner sus direcciones en manos de los obreros, resguardando la unidad, la democracia y la independencia sindical. ${ }^{51}$

El proceso eleccionario puso al PC al frente de la dirección de los gremios Químico, Madera, Construcción, Aceiteros, Prensa y Gastronómico de Capital, lo cual le permitió ganar posiciones para impulsar su programa unitario de oposición a la dictadura, tanto en el frente gremial como en el político.

\section{De la Comisión Intersindical a las 62 Organizaciones}

La realización de elecciones sindicales y la recuperación de los gremios por parte de los obreros, abrieron el camino hacia el armado de un organismo intergremial que guiara a los sindicatos hacia el objetivo de lograr la normalización de la CGT. El proceso de alza de la conflictividad social atravesado en 1956 -signado por la lucha en torno al mejoramiento de las condiciones de trabajo, por aumentos salariales y por la recuperación de los sindicatos y comisiones internas- dotó a los trabajadores de un saldo organizativo que se tradujo en la formación de nuevos agrupamientos, siendo la Comisión Intersindical de 1957 el primero de esos pasos significativos. ${ }^{52}$ Se asistió aquí a una conjunción de intereses entre el gremialismo comunista y peronista, los cuales encararon una lucha conjunta a lo largo del año alrededor de la recuperación de la central sindical. Entre los distintos agrupamientos sindicales de ese entonces, como la CGT Única e Intransigente, el Comando Sindical, la CGT Negra o la CGT Auténtica de 1957 (con Framini a la cabeza), la Comisión

\footnotetext{
49 “Elecciones sindicales” Nuestra Palabra n’319, 4/7/56, p.7

${ }^{50}$ Varía según el tamaño del sindicato: debe contar con el auspicio de 150 afiliados en gremios de menos de 3000 participantes o con el del 5\% de los afiliados en gremios con más de 3000.

51 "Por elecciones democráticas" Nuestra Palabra n³26, 22/8/56, p. 7.

52 Schneider, A. "Una lectura sobre las organizaciones de base del movimiento obrero argentino (19551973)". Archivos de historia del movimiento obrero y la izquierda. Año I, N² 2, marzo 2013, pp 33-54.
} 
Intersindical se convirtió en el primer organismo centralizado de dirección de la clase obrera tras la intervención de la CGT en noviembre de 1955.

El PC creó junto a los gremios normalizados una Comisión Provisoria Intersindical que marcó el origen del Movimiento Intersindical, compuesto por diversas comisiones en todo el país. El documento que plasmó el nacimiento del mismo fue un memorial presentado al presidente Aramburu el $1^{\circ}$ de marzo de 1957, en el que se expuso el Programa de Cinco puntos al que adherían 21 gremios: el mismo incluía la libertad de todos los trabajadores presos y confinados sin causa y sin proceso, la no aplicación de la ley 4144 a Eduardo Seijo, Antonio Losada y demás obreros en las mismas condiciones; que se complete el ciclo de normalización del movimiento obrero mediante el levantamiento de todas las intervenciones y la convocatoria, dentro del más breve plazo, a elección en los sindicatos que restan, en las Federaciones Nacionales y en la Confederación General del Trabajo; que se restablezcan los precios máximos para los artículos de primera necesidad y controles efectivos de las maniobras especulativas de toda índole y la elevación arbitraria de los mismos; que se garanticen las libertades y derechos sindicales mediante el levantamiento del estado de sitio y la vigencia de los derechos de huelga, prensa, reunión y palabra, como paso decisivo hacia la normalización institucional; y que se deroguen las leyes, decretos y resoluciones restrictivas de los derechos obreros y la ley $4144 .^{53}$

El Movimiento Intersindical se extendió al conjunto del país y protagonizó importantes luchas novedosas en el contexto de la dictadura. Al calor de la recuperación de los gremios por parte de sus trabajadores, las adhesiones a la Comisión Intersindical de CABA y GBA crecieron, así como se crearon nuevas Comisiones Intersindicales en distintos puntos del país. ${ }^{54}$ A nivel nacional, el Movimiento se organizó a partir del Plenario Nacional de la Intersindical, que se reunió cuatro veces en la primera mitad de 1957 con la participación de representantes de los gremios adheridos (fundamentalmente comunistas y peronistas) y de las distintas regionales de la CGT.

El PC interpretó el proceso a partir de una línea de continuidad entre el Movimiento Pro Democratización y el Movimiento Intersindical, cuyo eje se encontraba en la lucha por la unidad del movimiento obrero en base a los principios del "democratismo proletario" y la independencia de clase. Destacó en esa lucha la participación de los obreros sin distinción ideológica, lo cual disolvía la diferencia entre peronistas y no peronistas. Así, marcó el

\footnotetext{
${ }^{53}$ Los 21 gremios son: Federación Obreros Telefónicos (FOETRA), Sindicato Argentino de Prensa (SAP), Sindicato Obrero de la Industria Aceitera (SOIA), Sindicato del Personal de Industrias Químicas y Afines, Unión Obrera Industria de la Madera, Sindicatos Mecánicos Transporte Automotor, Sindicato Obreros de la Industria del Papel, Sindicato de Ceramistas, Sindicato Obreros Pasteleros, Pizzeros, Confiteros y Afines, Federación de Trabajadores de luz y fuerza, Sindicato Obreros y Empleados Vitivinícolas, Asociación Personal Aeronáutico, Sindicato Obrero de la Industria Aceitera de Avellaneda, Sindicato de Trabajadores de Agua y Energía eléctrica, Unión Trabajadores de la Industria del Calzado, Sindicato Petrolero de Avellaneda, Sindicato de Obreros y Empleados del Frigorífico "la Blanca", Unión Obreros Gastronómicos, Sindicato Mozos y Cocineros de Avellaneda. Ver Nuestra Palabra n³52, 6/3/57, p.3.

${ }^{54}$ Se destacan las Comisiones de Rosario, Córdoba, Tucumán, Mendoza, Paraná, Mar del Plata, San Juan, Junín, Cañada de Gómez, Misiones, San Rafael, La Plata, Pergamino, Chaco, Mercedes, Villa María, Venado Tuerto, Olavarría, Gualeguaychú, Quilmes, etc. Iscaro, R. Historia del movimiento sindical. (Tomo II). Buenos Aires, Editorial Fundamentos, 1973.
} 
Ezequiel Murmis, El Partido Comunista en el movimiento obrero argentino durante la "Revolución Libertadora": del golpe de estado a la alianza entre el sindicalismo comunista y peronista (1955-1958), Izquierdas, 28:114-136, Julio 2016

enfrentamiento entre defensores de la unidad de clase y sectores divisionistas ${ }^{55}$ : entre los primeros se ubicaban aquellos que participaban de la conformación de la Intersindical, sean estos peronistas o comunistas; entre los segundos figuraban principalmente los representantes del llamado "sindicalismo libre", el sector del sindicalismo antiperonista que apoyó el golpe, actuó como asaltante de sindicatos y fue cómplice de las intervenciones sindicales y las maniobras fraudulentas en las elecciones de los mismos. ${ }^{56}$ Este entramado de fuerzas es una clave determinante para comprender los sucesos del Congreso Normalizador de agosto de 1957.

Entre las acciones más importantes de cara al fortalecimiento de la organización de la clase obrera y a la imposición del programa de la Intersindical, se destacan el acto del $1^{\circ}$ de mayo en Plaza Once, el paro de una hora el 14 de junio en Capital y GBA contra la carestía de vida y el paro nacional del 12 de julio. La conmemoración del Día internacional de los Trabajadores no sólo fue la primera manifestación de la Intersindical en las calles, sino que se trató de la primera manifestación obrera opositora pública y legal desde el golpe de 1955. Promovido por la Comisión Intersindical de Capital y GBA, sostenido por el Plenario Nacional Intersindical, el acto congregó a decenas de miles de obreros de diversas tendencias en torno al programa de 5 puntos redactado por el PC. Además, el Partido ofició de orador a partir de la intervención de los dirigentes comunistas Vega, Moreira, Gómez Alcorta, Vázquez y Vincelli. De manera similar, ese programa fue el que guió el paro nacional de 24 hs convocado por la Intersindical para el 12 de julio, el cual contó, según cifras no oficiales, con la participación de 2.500 .000 de trabajadores. ${ }^{57}$

El contexto de alza de la conflictividad social impuso la necesidad de normalizar la situación de la CGT. El crecimiento de la Intersindical y sus muestras de fuerza permitieron incrementar la presión para realizar un Congreso Extraordinario, al tiempo que el Gobierno no debía dejar que el sindicalismo peronista y comunista sobrepasara al sindicalismo "libre", afín a sus intereses. El Plenario Nacional Intersindical propuso a los gremios avanzar en el proceso de conquista de la CGT a partir de la votación de Comisiones Provisorias en sus respectivas regionales, que impulsen a su vez la creación de una Comisión Provisoria Nacional de la CGT que exija su normalización. ${ }^{58}$ Frente a esto, el interventor de la misma se aprestó a convocar un Congreso Normalizador para el 26 de agosto, en el que se elegirían autoridades y adoptarían nuevos estatutos.

Tras obtenerse la normalización en los sindicatos quedaron delineados los sectores que intervenían en la lucha por reorganizar la CGT. El PC planteó que existía un sector mayoritario que absorbía a las minorías y contribuía a disgregar el movimiento obrero: el peronista (metalúrgicos, textiles, transporte, panaderos, sanidad, vitivinícolas, etc); y otro que respondía a los intereses de las patronales, el gobierno y el interventor al proponer una política sin contenido de clase: el sindicalismo "libre" (ferroviarios, mercantiles, vestido,

\footnotetext{
55 "El Movimiento Intersindical” Nuestra Palabra n³66, 12/6/57, p.4.

${ }^{56}$ La figura más destacada del sindicalismo libre era F. Pérez Leirós, dirigente sindicalista de tendencia socialista.

57 Schneider, Op Cit, 2005

58 "Por la unidad obrera hacia la normalización de la CGT" Nuestra Palabra n³67, 19/6/57, p.4
} 
Ezequiel Murmis, El Partido Comunista en el movimiento obrero argentino durante la "Revolución Libertadora": del golpe de estado a la alianza entre el sindicalismo comunista y peronista (1955-1958), Izquierdas, 28:114-136, Julio 2016

municipales, gráficos, etc.). El PC entendía que entre estos sectores figuraban fuerzas que buscaban la unidad del conjunto de la clase trabajadora a pesar de sus diferencias ideológicas, cuyo objetivo era hacer frente a la ofensiva patronal en materia económica y sindical: se trata del sindicalismo comunista, peronista de izquierda e independientes, al frente de sindicatos como luz y fuerza, construcción, madera, telefónicos, telegráficos, químicos, cerveceros, petroleros privados, etc. ${ }^{59}$

El PC recibió con satisfacción el llamado, aunque alertó acerca de las condiciones fraudulentas imperantes en el proceso de normalización en los sindicatos. En ese sentido, la Intersindical exhortó a los gremios adheridos a participar del Congreso bajo la urgencia que significaba para los trabajadores la recuperación de su órgano de representación para hacer frente a las problemáticas que la aquejaban, no sin destacar las maniobras de los interventores. En primer lugar, los organizadores buscaban limitar el temario a la discusión de estatutos y a la elección de autoridades, lo cual suponía -para el PC-poner en jaque los principios de democratismo proletario e independencia de clase ${ }^{60}$; a su vez, restringieron la participación de representantes de sindicatos con menos de mil afiliados; por último, el partido cuestionó el número de delegados de las organizaciones participantes en función de sus cotizantes, bajo la sospecha de una manipulación de los mismos en el caso de los sindicatos afines al gobierno.

Los acontecimientos que guiaron el desarrollo del Congreso Normalizador son determinantes para comprender el acercamiento entre el sindicalismo peronista y comunista de 1957: el fracaso del mismo tras el abandono de los "sindicatos libres" fue el escenario que permitió la alianza que daría origen a las "62 Organizaciones". El primer paso del Congreso fue la creación de una Comisión de Poderes encargada de evaluar la autenticidad de las credenciales de los 673 delegados representantes de 98 organizaciones. La obtención de la mayoría en la Comisión le permitió al "sindicalismo libre" aprobar las credenciales, al tiempo que las críticas se expresaron en los despachos por minoría. En el caso de los sindicatos comunistas, criticaron la inhabilitación de las organizaciones de menos de mil afiliados, así como reclamaron por el derecho de las delegaciones regionales a expresar sus opiniones. $^{61}$

La elección de la Comisión de Poderes confirmaba los cálculos del gobierno y el interventor, lo cual auguraba un triunfo del sector que auspiciaban. No obstante, la situación se revirtió frente a la moción de los Madereros (cuya conducción era comunista) en torno al problema de la proporcionalidad fijada a las representaciones: se propuso la designación de una Comisión Verificadora de 7 miembros para revisar los libros de las organizaciones, con el objetivo de aclarar las dudas en torno al número de cotizantes y a la proporción de delegados. ${ }^{62}$ Tras ganar la moción afirmativa, las 32 organizaciones del

\footnotetext{
${ }^{59}$ Iscaro, R. Op Cit., p. 334.

60 "Qué esperan los trabajadores del Congreso de la CGT" Nuestra Palabra n³76, 22/8/57, p.1.

${ }^{61}$ Gasparri, M. y Panella, C. El congreso normalizador de la CGT de 1957. La resistencia obrera y el surgimiento de las 62 Organizaciones. Corregidor, Buenos Aires, 2008.

62 "Manifestaciones unitarias jalonan las sesiones del Congreso de la CGT", Nuestra Palabra n³78, 5/9/57, p.5.
} 
Ezequiel Murmis, El Partido Comunista en el movimiento obrero argentino durante la "Revolución Libertadora": del golpe de estado a la alianza entre el sindicalismo comunista y peronista (1955-1958), Izquierdas, 28:114-136, Julio 2016

sindicalismo libre abandonaron el Congreso dejándolo sin quorum: lo que parecía un impasse resultó ser el final del desarrollo del mismo. A pesar de los intentos del sindicalismo comunista por reunir a las partes en pos de la continuación del proceso, el Congreso jamás se reanudó. Se produjo así un acercamiento entre los representantes de las organizaciones que se mantuvieron en la CGT: se trató de un total de 62 organizaciones, dirigidas en su mayoría por peronistas, en conjunción con el sector comunista e independiente. Se agruparon así los bandos antagónicos al interior del movimiento obrero: los “32 Gremios Mayoritarios y Democráticos" y las "62 Organizaciones".

Un aspecto central del proceso se encuentra en el rol que adquirió el PC en las 62 Organizaciones. El nuevo programa elaborado por "las 62" reunió los principales puntos de aquel presentado por la Intersindical, liderada por los comunistas. Los dirigentes más importantes del partido formaron parte la Mesa Coordinadora de las 62 Organizaciones y firmaban con sus nombres las Declaraciones de la misma: se trata de Vicente Marischi, histórico dirigente del gremio de la Madera, y José M. Zárate, dirigente de la Construcción. Desde el inicio de las reuniones entre los representantes de las 62 en octubre de 1957, las declaraciones de estado de alerta en los sindicatos incluyeron los puntos por los que lucharían las organizaciones adherentes: un aumento general de emergencia; la libertad inmediata de todos los presos y el levantamiento del estado de sitio; la derogación de los decretos 824 -que prorrogaba los convenios-, del que anulaba el derecho de huelga y el más reciente sobre la incentivación -que liquidaba las conquistas obreras; la solidaridad con los trabajadores de los gremios en lucha: telefónicos, telegráficos y demás; la reanudación del congreso de la CGT. ${ }^{63}$

Se advierte así una correspondencia entre ambos programas: abogaban por la libertad de los presos, los derechos sindicales y el levantamiento del Estado de sitio; se centraban en la normalización sindical; reclamaban por la situación salarial en el contexto de inflación y por la negociación de convenios colectivos. Los programas de la Intersindical y de las 62 Organizaciones expresaron los intereses de la clase trabajadora en el marco de la oposición a la Revolución Libertadora y fueron la base del acercamiento entre el sindicalismo comunista y peronista.

Luego del fracaso del Congreso Normalizador, "las 62" presentaron su programa al presidente de facto Aramburu, el cual fue enarbolado y reafirmado constantemente ${ }^{64}$ hasta la asunción de Frondizi, momento en que el PC abandonaría el nucleamiento y crearía, con sus 19 organizaciones, el Movimiento de Unidad Sindical Clasista (MUCS). En esos meses, el rechazo de los puntos reclamados por parte del Gobierno llevó a "las 62" a realizar los paros generales del 27 de septiembre y 22 de octubre, de 24 y $48 \mathrm{hs}$ respectivamente. El alza de la conflictividad y el salto organizativo de la clase obrera tuvo su respuesta inmediata

\footnotetext{
63 "Llamamiento a reforzar el estado de alerta de todos los gremios del país" Nuestra Palabra n³83, 10/10/57, p.4.

64 "La unidad del movimiento obrero y las luchas reivindicativas" Nuestra Palabra no 390 28/11/57, p.4 y 5;, "Grupos perturbadores y la policía impidieron concretar la lucha por aumento de salario" Nuestra Palabra $\mathrm{n}^{\circ}$ 393 19/12/57, p.1; “Comunicado de las 62” Nuestra Palabra n 398 23/1/58, p.6; "Comunicado de las 62” Nuestra Palabra n 399 30/1/58, p.6; "Los 62 gremios están contra los golpes de estado, el quedantismo y el continuismo" Nuestra Palabra no 401 13/2/58, p.2.
} 
Ezequiel Murmis, El Partido Comunista en el movimiento obrero argentino durante la "Revolución Libertadora": del golpe de estado a la alianza entre el sindicalismo comunista y peronista (1955-1958), Izquierdas, 28:114-136, Julio 2016

con el decreto de reglamentación de huelgas, los decretos de incentivación del trabajo y las detenciones en masa. A su vez, se intervino nuevamente la Asociación de Trabajadores del Estado (ATE), la Federación del Aceite y el Sindicato Gastronómico de Capital; y se dispuso la movilización militar de ferroviarios, municipales, aeronáuticos y portuarios todos gremios en conflicto. Tras el segundo paro, vinieron las intervenciones de la Unión Tranviarios Automotor (UTA) y varias seccionales de la Unión Ferroviaria (UF). ${ }^{65}$

En este marco, las proclamas de "las 62" adquirieron un mayor grado de politización, lo cual se plasmó en el Programa de La Falda. En esa reunión convocada para noviembre por las Regionales de la CGT participaron las 62 Organizaciones y se aprobaron, no solamente el reclamo de cinco puntos defendido por los gremios peronistas y comunistas $^{66}$, sino un programa político que recordaba las 'banderas históricas' del peronismo: la independencia económica, la soberanía política y la justicia social. Entre sus puntos más importantes se destacaban la apuesta por el control estatal del comercio exterior, la liquidación de los monopolios extranjeros de importación y exportación, desarrollo de la industria, nacionalizaciones, control obrero de la producción, participación obrera en la confección de los planes de gobierno, destrucción de los sectores oligárquicos, etc. ${ }^{67}$ Es importante señalar que, en este evento significativo para la historia de la clase obrera y de la resistencia, tres fueron los principales oradores: José Rucci, Eleuterio Cardozo, entre los peronistas, y Vicente Marischi, como dirigente comunista. ${ }^{68}$

Desde la óptica del PC, la descomposición de "las 62" comenzó precisamente cuando "algunos dirigentes sectarios peronistas retomaron las posiciones intransigentes y exclusivistas que habían adoptado en el congreso de 1957 y quisieron convertir a "las 62" en un nucleamiento partidario". ${ }^{69}$ Las coincidencias entre peronistas y comunistas en el movimiento obrero llegaron hasta el apoyo brindado por "las 62" a la candidatura de Frondizi, que lo llevaron a la Presidencia de la República tras el triunfo de las elecciones de febrero. La fractura tuvo lugar a partir de diferencias en torno a la sanción de la Ley de Asociaciones Profesionales, en cuyas deliberaciones el sector peronista demostró el peso adquirido al interior de las 62 Organizaciones. En acuerdo con el frondicismo, el sector peronista aceptó la realización de elecciones sindicales con la intervención de veedores designados por el gobierno, propuesta incluida en el punto 4 del Memorial presentado a

\footnotetext{
${ }^{65}$ Melon Pirro, J. C. El peronismo después del peronismo. Resistencia, sindicalismo y política luego del 55. Siglo XXI, Buenos Aires, 2009.

${ }^{66}$ Los mismos fueron: $1^{\circ}$ ) Libertad inmediata a los obreros detenidos; $2^{\circ}$ ) Derogación del decreto sobre huelga; $3^{\circ}$ ) Derogación del decreto 824 que congela los salarios y de los 7 decretos regresivos de incentivación del trabajo; $4^{\circ}$ ) Aumento de emergencia solicitado por todos los gremios, sin que ello implique la renuncia a formalizar nuevos convenios colectivos; $5^{\circ}$ ) Reanudación inmediata del Congreso de la CGT. Ver "Las regionales de la CGT apoyan los cinco puntos de las 62 Organizaciones" Nuestra Palabra n” 391, 5/12/57, p. 4.

${ }^{67}$ El Programa de la Falda puede ser consultado online: http://www.cgtargentinos.org/documentos.htm

${ }^{68}$ Gasparri y Panella $O p$ Cit. Entrevista a S. Senén González p. 51.

${ }^{69}$ Iscaro, Op Cit., p. 341.
} 
Ezequiel Murmis, El Partido Comunista en el movimiento obrero argentino durante la "Revolución Libertadora": del golpe de estado a la alianza entre el sindicalismo comunista y peronista (1955-1958), Izquierdas, 28:114-136, Julio 2016

Frondizi en marzo de $1958^{70}$. El objetivo que se perseguía era la devolución de la CGT al peronismo, relegando al PC de las posiciones de poder en el movimiento obrero.

A pesar de la efímera alianza y de que la CGT no fue devuelta a sus trabajadores hasta 1963, el surgimiento de "las 62" fue un hecho destacado en tanto sirvió a la reorganización del movimiento obrero: aunque en sus orígenes el comunismo fue una de las fuerzas principales, 1958 muestra ser el año que se inaugura con un sindicalismo en el que el peronismo reconstruye su hegemonía.

\section{Conclusiones}

En el marco de la Revolución Libertadora de 1955-1958, el Partido Comunista propugnó luchar de la mano de fuerzas democráticas y progresistas a partir del armado de un Frente Democrático Nacional, para la conformación de un Gobierno de Coalición Democrática. Basada en la estrategia de Frente Popular, la misma tuvo su correlato en el mundo del trabajo, en donde el partido buscó unificar a los diversos sectores obreros sin distinción política ni religiosa para derrotar a la dictadura y la intervención sindical: su participación en los conflictos, en las comisiones paritarias y en las elecciones sindicales fueron una muestra de ello.

En este artículo hemos buscado demostrar que el Partido Comunista fue un actor significativo de este período de Resistencia. Tras su accionar titubeante en los meses de Lonardi en el gobierno, su intervención en términos de lucha unitaria -desplegada fundamentalmente a partir de 1956- le permitió conquistar posiciones en el mundo del trabajo, lo cual se tradujo en un crecimiento en materia organizativa para el movimiento obrero. Al frente de nuevos sindicatos, el PC se puso a la cabeza de la Comisión Intersindical, cuya creación en 1957 logró expresar la capacidad organizativa adquirida por el partido y los trabajadores al calor de las luchas en el contexto de la dictadura. La extensión del movimiento a nivel nacional puso al PC nuevamente en el mapa sindical como un actor central, lugar que no ocupaba desde los años ' 40 y el advenimiento del peronismo.

La relevancia de este nucleamiento sindical se advirtió en dos sentidos: en primer lugar, su fuerza creciente permitió presionar al Gobierno para que organizara el Congreso Normalizador de la CGT en 1957; en segundo, tras el fracaso del mismo, sirvió de base para la conformación de un nuevo agrupamiento como lo fueron las 62 Organizaciones. De este modo, demostramos que el PC fue uno de los pilares en la creación de la que sería, durante años, la organización sindical más importante a nivel nacional.

En paralelo, este proceso muestra su importancia al señalar un elemento novedoso en la política nacional: la primera alianza entre peronistas y comunistas de la historia. Ambos sectores participaron en la Intersindical y conformaron las 62 Organizaciones siguiendo un programa de cinco puntos con grandes similitudes. Si bien juntos encabezaron importantes conflictos y presionaron por la democratización del país, esa alianza se vió

70 "Para llevar a cabo el programa de "las 62" presentado a Frondizi" Nuestra Palabra no 407, 27/3/58, p.6 
Ezequiel Murmis, El Partido Comunista en el movimiento obrero argentino durante la "Revolución Libertadora": del golpe de estado a la alianza entre el sindicalismo comunista y peronista (1955-1958), Izquierdas, 28:114-136, Julio 2016

fracturada a poco de comenzado el gobierno de Frondizi, a partir de la sanción de la Ley de Asociaciones Profesionales, que contó con el apoyo del sindicalismo peronista y la negativa del comunista.

Recibido: 25 enero 2016 Aceptado: 24 marzo 2016

\section{Bibliografía}

Camarero, H. "Una experiencia de la izquierda en el movimiento obrero. El trotskismo frente a la crisis del peronismo y la resistencia de los trabajadores (1954-1957)", Razón y Revolución n 3 , invierno 1997.

Camarero, H. "El tercer período de la Comintern en versión criolla. Avatares de una orientación combativa y sectaria del Partido Comunista hacia el movimiento obrero argentino" $A$ Contracorriente, vol. VII, 2011, North Carolina (USA), pp. 203-232.

Camarero, H. "Tras las huellas de una ilusión: el Partido Comunista argentino y sus planteos del Frente Democrático Nacional (1955-1963)". Revista Archivos de historia del movimiento obrero y la izquierda. Año III, $\mathrm{N}^{\circ}$ 5, sept. 2014, p. 31.

Camarero, H. y Ceruso. D. "Una historia del sindicato de la madera: organización gremial e influencia de la izquierda en las luchas obreras, Buenos Aires, 1917-1943" e-1@tina, Vol. 13, num. 50, Buenos Aires, enero-marzo 2015

Ceruso, D. La izquierda en la fábrica. La militancia obrera industrial en el lugar de trabajo, 19161943. Imago Mundi, Buenos Aires, 2015.

Contreras, G. "La organización del movimiento obrero durante el primer peronismo (1946 - 1955): nucleamientos sindicales y centrales obreras. Primeros avances de investigación y propuestas para un análisis desde la historia social y la historia política" V Jornadas Nacionales de Historia Social, La Falda, Córdoba, 2015.

Gilbert, I. El oro de Moscú. Historia secreta de la diplomacia, el comercio y la Inteligencia soviética en la Argentina. Planeta, Buenos Aires, 1994.

González, E. (coord.) El trotskismo obrero e internacionalista en la Argentina. Tomo II. Antídoto, Buenos Aires, 1996

Gurbanov, A. y Rodríguez, S. "La huelga metalúrgica de 1942 y la dirigencia comunista en los orígenes del peronismo". Nuevo Topo no 4, Buenos Aires, 2007, pp. 61-83

James, D. Resistencia e integración. El peronismo y la clase trabajadora argentina. Siglo XXI, Buenos Aires, 2006

Kabat. M. "Resistencia obrera a la flexibilidad laboral, un análisis de la negociación colectiva en 1954." XIV Jornadas Interescuelas/Departamentos de Historia, Universidad Nacional de Cuyo, Mendoza, 2013

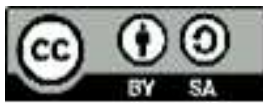


Ezequiel Murmis, El Partido Comunista en el movimiento obrero argentino durante la "Revolución Libertadora": del golpe de estado a la alianza entre el sindicalismo comunista y peronista (1955-1958), Izquierdas, 28:114-136, Julio 2016

Lobato, M. La vida en las fábricas. Trabajo, protesta y política en una comunidad obrera, Berisso (1904-1970). Prometeo, Buenos Aires, 2001.

Mangiantini, M. El trotskismo y el debate en torno a la lucha armada. Moreno, Santucho y la ruptura del PRT. El Topo Blindado, Buenos Aires, 2014.

Mastrángelo, M. Rojos en la Córdoba obrera 1930-1943. Imago Mundi, Buenos Aires, 2011

Melon Pirro, J. C. El peronismo después del peronismo. Resistencia, sindicalismo y política luego del 55. Siglo XXI, Buenos Aires, 2009.

Murmis, E. "Balances y perspectivas: acerca de la historiografía sobre el Partido Comunista argentino. Desde sus orígenes hasta los años '60." XV Jornadas Interescuelas, Universidad Nacional de la Patagonia San Juan Bosco, Comodoro Rivadavia, septiembre 2015.

Peralta Ramos, M. Acumulación de capital y crisis política en la Argentina (1930-1974). Siglo XXI, Buenos Aires, 1973.

Portantiero, J. C. "Economía y política en la crisis argentina, 1958-1973", en Ansaldi, W. y Moreno, J. L. (comp.), Estado y sociedad en el pensamiento nacional, Buenos Aires, Cántaro, 1996, pp. 301346.

Sánchez, M. "El sindicalismo del PC en la UF ante los planes de racionalización ferroviaria (19551970)". VI Jornadas de la División Historia - III Taller de Historia Regional. Universidad Nacional de Luján. Luján, 2015

Schiavi, M. La resistencia antes de la resistencia. La huelga metalúrgica y las luchas obreras en 1954, El Colectivo, Buenos Aires, 2008.

Schiavi, M. "Los sindicatos comunistas entre el 17 de octubre y su disolución. El caso textil y metalúrgico." Trabajadores, Año II. N 3, 2012.

Schneider, A. Los compañeros. Trabajadores, izquierda y peronismo (1955-1973). Imago Mundi, Buenos Aires, 2005, p.71.

Schneider, A. "Una lectura sobre las organizaciones de base del movimiento obrero argentino (1955-1973)". Archivos de historia del movimiento obrero y la izquierda. Año I, N² 2, marzo 2013, pp 33-54.

Staltari, S. "El Partido Comunista frente al peronismo: estrategia y tácticas políticas, 1945-1955" Revista Archivos de historia del movimiento obrero y la izquierda. Año III, N 5, 2014, pp 11- 30.

Tortti, M. C. El "viejo" Partido Socialista y los orígenes de la "Nueva Izquierda”. Tesis Doctoral. Universidad Nacional de La Plata. Facultad de Humanidades y Ciencias de la Educación, 2007. Disponible en: http://www.memoria.fahce.unlp.edu.ar/tesis/te.259/te. 259.pdf

Videla, O. y Menotti, P. "Una experiencia de la militancia comunista en los orígenes del peronismo. El Sindicato de Obreros de la Industria Metalúrgica (SOIM) de Rosario" A contracorriente, $\mathrm{n}^{\circ} 2$, vol. 11, 2014, pp. 114-144.

Fuentes

Nuestra Palabra (semanario del Partido Comunista Argentino) - septiembre 1955/mayo 1958.

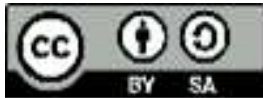

